\title{
High Virulence and Antifungal Resistance in Clinical Strains of Candida albicans
}

\author{
Eric Monroy-Pérez, Gloria Luz Paniagua-Contreras, Pamela Rodríguez-Purata, \\ Felipe Vaca-Paniagua, Marco Vázquez-Villaseñor, Clara Díaz-Velásquez, \\ Alina Uribe-García, and Sergio Vaca
}

\begin{abstract}
Facultad de Estudios Superiores Iztacala, Universidad Nacional Autónoma de México, Av. de los Barrios 1,
\end{abstract} Los Reyes Iztacala, 54090 Tlalnepantla, MEX, Mexico

Correspondence should be addressed to Sergio Vaca; vacasergio@gmail.com

Received 11 October 2016; Accepted 21 November 2016

Academic Editor: Jorge Garbino

Copyright ( 2016 Eric Monroy-Pérez et al. This is an open access article distributed under the Creative Commons Attribution License, which permits unrestricted use, distribution, and reproduction in any medium, provided the original work is properly cited.

Antifungal resistance and virulence properties of Candida albicans are a growing health problem worldwide. To study the expression of virulence and azole resistance genes in 39 clinical strains of C. albicans, we used a model of infection of human vaginal epithelial cells with C. albicans strains isolated from Mexican women with vulvovaginal candidiasis (VVC). The strains were identified by PCR amplification of the ITS1 and ITS2 regions of rRNA. The detection and expression of virulence genes and azole resistance genes $M D R 1$ and CDR1 were performed using PCR and RT-PCR, respectively. All strains were sensitive to nystatin and 38 (97.4\%) and 37 (94.9\%) were resistant to ketoconazole and fluconazole, respectively. ALS1, SAP4-SAP6, LIP1, LIP2, LIP4, LIP6, LIP7, LIP9, LIP10, and PLB1-PLB2 were present in all strains; SAP1 was identified in 37 (94.8\%) isolates, HWP1 in 35 (89.7\%), ALS3 in 14 (35.8\%), and CDR1 in 26 (66.6\%). In nearly all of the strains, ALS1, HWP1, SAP4-SAP6, LIP1-LIP10, PLB1, and PLB2 were expressed, whereas CDR1 was expressed in $20(51.3 \%)$ and ALS3 in 14 (35.8\%). In our in vitro model of infection with C. albicans, the clinical strains showed different expression profiles of virulence genes in association with the azole resistance gene CDR1. The results indicate that the strains that infect Mexican patients suffering from VVC are highly virulent and virtually all are insensitive to azoles.

\section{Introduction}

Candida albicans is an opportunistic fungus that infects the mucosae of oral and vaginal cavities [1]. Vulvovaginal candidiasis (VVC) is among the most common infections that affect women of childbearing age [2]. Clinical strains of $C$. albicans possess an array of virulence genes that directly influence the pathogenesis of VVC, including genes responsible for phenotypic switching [3], HWP1 (hyphal wall protein 1) [4], ALS (agglutinin-like sequence) [5], SAP (secreted aspartyl proteases) [6], $P L$ (phospholipases) [7], and LIP (lipases) [8]. The aspartyl proteases, phospholipases, and lipases are involved in the breakdown of cell membranes in host epithelia, which promotes colonization and invasion [9].

The increase of $C$. albicans resistant to antifungal agents, mainly to azoles, is a serious health problem and hampers the treatment of VVC. The mechanisms responsible for resistance to azoles include overexpression of CDR1 and
$C D R 2$ from the $\mathrm{ABC}$ transporter family and MDR1 which encodes a multidrug efflux pump. Mutations in ERG5 and $E R G 11$, which cause alterations in C22-desaturase and sterol $14 \alpha$-demethylase, respectively, are also associated with azole resistance [10].

The expression of ALS and SAP gene families in C. albicans of vaginal origin has recently been studied [11, 12]. Likewise, the gene expression patterns of the LIP and PL family, which are associated with the formation of biofilm during infection, have been studied [13]. However, the expression patterns of ALS, HWP1, SAP, LIP, and PLB in association with azole resistance genetic determinants have been less studied in strains of vaginal origin. In this work, to analyse the expression patterns of ALS1-ALS3, HWP1, SAP1, SAP4-SAP6, LIP1-LIP10, PLB1-PLB2, CDR1, and MDR1, we implemented an in vitro model of infection of human vaginal cells with $C$. albicans strains isolated from women with VVC. 


\section{Materials and Methods}

2.1. Patients Analysed and Sampling. Our study included a group of 200 women (ages 18-57) who attended the gynaecology department of public hospitals in the State of Mexico, Mexico, and presented characteristic symptoms of VVC (itching, burning, dysuria, and curd-like discharge). In this study, adult women with/without active sexual life were included. The exclusion criteria were as follows: patients with cervical cancer, being pregnant, being under antibiotic treatment, or having ingested antifungal drugs in the last 30 days. In addition, the patients informed if they had been previously exposed to azoles at least once in the last year as treatment for VVC. All participating women signed a letter of informed consent. The ethics committee of each hospital approved the study. Two samples were taken from the cervicovaginal cavity of each patient, using sterile swabs. The first was used to observe the presence of yeast, hyphae, or pseudohyphae by light microscopy. The second was incubated for $24 \mathrm{~h}$ at $37^{\circ} \mathrm{C}$ in brain heart infusion (BHI) medium (BD Bioxon, Cuautitlan Izcalli, State of Mexico, Mexico). After $24 \mathrm{~h}$, the samples were incubated at $37^{\circ} \mathrm{C}$ in Sabouraud agar plates (BD Bioxon) with $50 \mu \mathrm{g} / \mathrm{mL}$ chloramphenicol.

2.2. Identification of C. albicans. C. albicans strains were identified by the API 20 C Aux test (bioMerieux, Durham, NC, USA), germ tube test [11], and PCR amplification of ITS1 and ITS2 rRNA loci (the primers are shown in Table 1) [14]. The DNA of the strains was extracted by boiling, as described by Paniagua-Contreras et al. [15]. The C. albicans strain B311 (ATCC 32354, ATCC, Manassas, VA, USA) was used as a positive control.

2.3. Antifungal Susceptibility. To test C. albicans antifungal susceptibility, we used diffusion disks impregnated with $25 \mu \mathrm{g}$ of fluconazole, $10 \mu \mathrm{g}$ of ketoconazole, and $100 \mathrm{U}$ nystatin (HiMedia Laboratories, Mumbai, India). Antifungal susceptibility was established according to the interpretation criteria previously described (Table 2) [16].

2.4. Detection of Genetic Virulence Markers and Azole Resistance Genes by PCR. The primers and PCR conditions used were previously described: ALS1 and ALS3 [17], HWP1 [18], SAP1 [19], SAP4-SAP6 [20], LIP1-LIP10 and PLB1-PLB2 [13], and CDR1 and MDR1 [21] (Table 1).

2.5. In Vitro Infection Model. To study the expression of virulence markers and azole resistance genes, we used the A431 cell line (ATCC CRL-1555), which is derived from a vulvar epidermoid carcinoma. The growth conditions of the strains were previously reported $[22,23]$. The A431 cell culture was inoculated with $50 \mu \mathrm{L}$ of phosphate-buffered saline (PBS) with $2 \times 10^{6} \mathrm{C}$. albicans cells. The mixed cultures were incubated for $72 \mathrm{~h}$ at $37^{\circ} \mathrm{C}$ in $5 \% \mathrm{CO}_{2}$. The culture medium was changed every 24 h. C. albicans (ATCC 32354) and Staphylococcus epidermidis (ATCC 35984) were used as positive and negative controls, respectively.
2.6. RNA Purification and cDNA Synthesis. After infection of A431 cells, the yeasts were harvested and suspended in $200 \mu \mathrm{L}$ of buffer Y1 (Qiagen, Hilden, Germany) with lyticase (50 U/10 ${ }^{7}$ cells). Samples were incubated for $20 \mathrm{~min}$ at $30^{\circ} \mathrm{C}$ with gentle agitation to facilitate the formation of spheroplasts. Total RNA was purified on a robotic QIAcube workstation (Qiagen) using the RNeasy Mini Kit (Qiagen), following the manufacturer's instructions, including DNase treatment. The concentration and purity of total RNA were analysed on a NanoDrop spectrophotometer 2000 (Thermo Scientific, Waltham, MA, USA). cDNA was synthesized with the QuantiTect Reverse Transcription kit (Qiagen) according to manufacturer's instructions.

2.7. Amplification and Detection of the Azole Resistance and Virulence Genes. Amplification and detection of azole resistance and virulence genes were performed using real-time PCR with the Rotor-Gene SYBR Green PCR kit (Qiagen). The primer sequences used for the gene expression analysis are shown in Table 1 . The final volume of each reaction was $25 \mu \mathrm{L}$, consisting of $12.5 \mu \mathrm{L}$ of SYBR Green Master Mix, $1 \mu \mathrm{L}$ of forward primer $(1 \mu \mathrm{M}), 1 \mu \mathrm{L}$ of reverse primer $(1 \mu \mathrm{M}), 2 \mu \mathrm{L}$ of cDNA ( 20 ng), and $8.5 \mu \mathrm{L}$ RNase-free water. Amplification conditions were $95^{\circ} \mathrm{C}$ for $5 \mathrm{~min}, 40$ cycles at $95^{\circ} \mathrm{C}$ for $5 \mathrm{~s}$, and combination alignment/extension at $60^{\circ} \mathrm{C}$ for $10 \mathrm{~s}$. The amplification conditions for the positive and negative controls were the same as described above.

\section{Results}

3.1. Identification of C. albicans and Antifungal Resistance Phenotypes. C. albicans was identified in $19.5 \%(n=39)$ of the samples and, in the remaining ones $(80.5 \%, n=161)$, bacteria such as Escherichia coli, Klebsiella spp., Staphylococcus aureus, or Staphylococcus epidermidis were found.

All 39 isolates were sensitive to nystatin, whereas $97.4 \%$ $(n=38)$ and $94.9 \%(n=37)$ were resistant to fluconazole and ketoconazole, respectively (Table 3 ). Resistance to both azoles was found in $94.9 \%(n=37)$ of the strains.

3.2. Detection of Virulence Markers and Azole Resistance Genes. All of the isolated strains $(n=39)$ were carriers of the ALS1, SAP4-SAP6, LIP1, LIP2, LIP4, LIP6, LIP7, LIP9, LIP10, and $P L B 1-P L B 2$ genes. Other genes detected were $S A P 1$ in 94.8\% ( $n=37)$, HWP1 $(89.7 \%, n=35), \operatorname{ALS3}(35.8 \%, n=14)$, and CDR1 $(66.6 \%, n=26)$ of the strains (Table 4$)$.

3.3. Expression Patterns of the Virulence Genes and CDR1. In nearly all of the isolates, ALS1, HWP1, SAP4-SAP6, LIP1LIP10, PLB1, and PLB2 were expressed after infection of the cell line A431, whereas CDR1 was expressed in 20 (51.3\%) and ALS3 in 14 (35.8\%) (Table 4).

Fourteen distinct expression patterns of $A L S, H W P 1, S A P$, $P L B, L I P$, and CDR1 were identified (Table 5). The most prevalent expression profile, Pattern 1, composed of 18 genes, was found in $25.6 \%(n=10)$ of the strains. Pattern 2 included 20 expressed genes and was found in $18 \%(n=7)$; Patterns 3 and 4, both expressing 19 genes, were detected in $12.8 \%$ (5 
TABLE 1: Primers used in PCR and real-time PCR assays.

\begin{tabular}{|c|c|c|}
\hline Gene & Orientation & Sequence $5^{\prime}$ to $3^{\prime}$ \\
\hline \multirow{2}{*}{ rRNA } & FW & TTTATCAACTTGTCACACCAGA \\
\hline & $\mathrm{RV}$ & ATCCCGCCTTACCACTACCG \\
\hline \multirow{2}{*}{ ALS1 } & FW & CCATCACTGAAGATATCACCACA \\
\hline & $\mathrm{RV}$ & TGGAGCTTCTGTAGGACTGGTT \\
\hline \multirow{2}{*}{ ALS3 } & FW & CCAAGTGTTCCAACAACTGAAA \\
\hline & RV & GAACCGGTTGTTGCTATGGT \\
\hline \multirow{2}{*}{$H W P 1$} & FW & CCATGTGATGATTACCCACA \\
\hline & RV & GCTGGAACAGAAGATTCAGG \\
\hline \multirow{2}{*}{ SAP1 } & FW & TCAATCAATTTAСТСТTCСАТTTCTAАСА \\
\hline & $\mathrm{RV}$ & CCAGTAGCATTAACAGGAGTTTTAATGACA \\
\hline \multirow{2}{*}{ SAP4 } & FW & TTATTTTTAGATATTGAGCCCACAGAAA \\
\hline & RV & GCCAGTGTCAACAATAACGCTAAGTT \\
\hline \multirow{2}{*}{ SAP5 } & FW & AGAATTTCCCGTCGATGAGACTGG \\
\hline & RV & CAAATTTTGGGAAGTGCGGGAAGA \\
\hline \multirow{2}{*}{ SAP6 } & FW & CCCGTTTTGAAATTAAATATGCTGATGG \\
\hline & $\mathrm{RV}$ & GTCGTAAGGAGTTCTGGTAGCTTCG \\
\hline \multirow{2}{*}{ LIP1 } & FW & AGCCCAACCAGAAGCTAATGAA \\
\hline & RV & TGATGCAAAAGTCGCCATGT \\
\hline \multirow{2}{*}{ LIP2 } & FW & GGCCTGGATTGATGCAAGAT \\
\hline & RV & TTGTGTGCAGACATCCTTGGA \\
\hline \multirow{2}{*}{ LIP3 } & FW & TCTCACCGAGATTGTTGTTGGA \\
\hline & RV & GTTGGCCATCAAATCTTGCA \\
\hline \multirow{2}{*}{ LIP4 } & FW & GCGTCCTGTTGCTTTCACT \\
\hline & RV & ACACGGTTTGTTTTCCATTGAA \\
\hline \multirow{2}{*}{ LIP5 } & FW & TGGTTCCAAAAATACCGTGTT \\
\hline & RV & CGACAATAGGGACGATTTGATCA \\
\hline \multirow{2}{*}{ LIP6 } & FW & AAGAATCTTCCGACCTGACCAA \\
\hline & $\mathrm{RV}$ & ATATGCACCTGTTGACGTTCAAA \\
\hline \multirow{2}{*}{ LIP7 } & FW & AACTGATATTTGCCATGCATTAGAAA \\
\hline & RV & CCATTCCCGGTAACTAGCATGT \\
\hline \multirow{2}{*}{ LIP8 } & FW & CAACAATTGCTAAAATCGTTGAAGA \\
\hline & RV & AGGGATTTTTGGCACTAATTGTTT \\
\hline \multirow{2}{*}{ LIP9 } & FW & CGCAAGTTTGAAGTCAGGAAAA \\
\hline & RV & CCCACATTACAATTTGGCATCT \\
\hline \multirow{2}{*}{ LIP10 } & FW & CACCTGGCTTAGCAGTTGCA \\
\hline & RV & CCCAGCAAAGACTCATTTTATTCA \\
\hline \multirow{2}{*}{$P L B 1$} & FW & GGTGGAGAAAGATGGCCAAAA \\
\hline & RV & AGCACTTACGTTACGATGCAACA \\
\hline \multirow{2}{*}{ PLB2 } & FW & TGAAACCTTTGGGCGACAACT \\
\hline & RV & GCCGCGCTCGTTGTTAA \\
\hline \multirow{2}{*}{ CDR1 } & FW & AAGAGAACCATTACCAGG \\
\hline & RV & AGGAATCGACGGATCAC \\
\hline \multirow{2}{*}{$M D R 1$} & FW & GGAGTTTAGGTGCTGT \\
\hline & $\mathrm{RV}$ & CGGTGATGGCTCTCAA \\
\hline
\end{tabular}


TABLE 2: Interpretive criteria of susceptibility and resistance to antifungals used in this study.

\begin{tabular}{lccc}
\hline $\begin{array}{l}\text { Antifungal } \\
\text { drugs }\end{array}$ & \multicolumn{3}{c}{ Zone diameter $(\mathrm{mm})$} \\
Ketoconazole & $\geq 30$ & $23-29$ & $\leq 22$ \\
Fluconazole & $\geq 19$ & $15-18$ & $\leq 14$ \\
Nystatin & $\geq 25$ & $17-24$ & $\leq 14$ \\
\hline
\end{tabular}

TABLE 3: Susceptibility and resistance of Candida albicans strains to antifungal drugs.

\begin{tabular}{lcc}
\hline Antifungal drugs & $\begin{array}{c}\text { Resistant } \\
\text { Number (\%) }\end{array}$ & $\begin{array}{c}\text { Sensitive } \\
\text { Number (\%) }\end{array}$ \\
\hline Nystatin & $0(0)$ & $39(100)$ \\
Fluconazole & $37(94.9)$ & $2(5.1)$ \\
Ketoconazole & $38(97.4)$ & $1(2.6)$ \\
\hline
\end{tabular}

TABle 4: Percentages of detection and expression of virulence markers and azole resistance genes in Candida albicans strains.

\begin{tabular}{lcc}
\hline Gene & $\begin{array}{c}\text { Detection } \\
\text { Number }(\%)\end{array}$ & $\begin{array}{c}\text { Expression } \\
\text { Number }(\%)\end{array}$ \\
\hline ALS1 & $39(100)$ & $39(100)$ \\
ALS3 & $14(35.8)$ & $14(35.8)$ \\
HWP1 & $35(89.7)$ & $35(89.7)$ \\
SAP1 & $37(94.8)$ & $36(92.3)$ \\
SAP4 & $39(100)$ & $39(100)$ \\
SAP5 & $39(100)$ & $39(100)$ \\
SAP6 & $39(100)$ & $39(100)$ \\
LIP1 & $39(100)$ & $39(100)$ \\
LIP2 & $39(100)$ & $39(100)$ \\
LIP3 & $38(97.4)$ & $38(97.4)$ \\
LIP4 & $39(100)$ & $39(100)$ \\
LIP5 & $35(89.7)$ & $35(89.7)$ \\
LIP6 & $39(100)$ & $39(100)$ \\
LIP7 & $39(100)$ & $39(100)$ \\
LIP8 & $38(97.4)$ & $38(97.4)$ \\
LIP9 & $39(100)$ & $39(100)$ \\
LIP10 & $39(100)$ \\
PLB1 & $39(100)$ & $39(100)$ \\
PLB2 & $39(100)$ & $20(51.3)$ \\
CDR1 & $39(100)$ & $0(0)$ \\
MDR1 & $26(66.6)$ &
\end{tabular}

strains); Patterns 5 (18 genes) and 6 (19 genes) were detected in $5.1 \%(n=2)$ (Table 5$)$. The following eight expression patterns (Patterns 7-14) were represented by a single strain. CDR1 was found in eight different patterns $(n=20)$.

\section{Discussion}

In this study, we isolated and identified the virulence gene expression patterns of C. albicans strains in $19.5 \%$ of 200 vaginal samples. VVC is a condition that affects a quarter of young women $[2,24]$. The presence of E. coli, Klebsiella spp., $S$. aureus, or S. epidermidis in most vaginal samples $(n=161)$ agrees with previous reports showing bacterial vaginitis as the first cause of vaginal infections [24].

The chronicity of VVC or recurrent episodes by $C$. albicans is due to prolonged use of antifungals, which select for resistant strains, and due to the numerous virulence genotypes that promote adhesion to epithelial cells, production of hydrolytic enzymes, colonization, and invasion [9]. We found that each strain isolated that carried ALS1 (39/39) and ALS3 $(14 / 14)$ was able to express these genes in the in vitro model of infection (Table 4). The frequency of expression of the ALS genes reported here is similar to those reported in vaginal candidiasis models [25]. The ALS proteins are extracellular components of the cell membrane which mediate adhesion and colonization of host cells [26,27]. Widespread expression of these proteins in the isolated strains supports their role in infection.

All strains positive for HWP1 (35/35) expressed this gene during infection of A431 cells (Table 4). The frequency of expression is higher than results reported in C. albicans strains isolated from women with vaginal infection in Turkey [28]. The high frequency of expression of HWP1 and the $A L S$ genes found in this study (Table 4) reveals the capacity of the isolated strains to cause chronic vaginal infections. This result is consistent with reports showing that the combined expression of the adhesion proteins HWP1 and ALS1ALS3 significantly facilitates biofilm formation [29] and can participate in the resistance to antifungals by limiting their penetrance to the biofilm [30].

Likewise, all isolated strains expressed SAP4-SAP6 (39/ 39) and almost all expressed SAP1 (92.3\%, (36/37)) (Table 4). These results are similar to those previously described for $S A P$ expression in VVC in humans [31]. The expression of SAP4-SAP6 has a relevant role in pathogenesis by promoting hyphae formation [32] and by the inhibition of phagocytosis [33].

In this study, most strains expressed genes of the LIP family, except LIP3, LIP5, and LIP8 (Table 4). These data are consistent with those reported using an in vitro infection model of oral epithelial cells and in patient samples [34]. The specific role of LIP proteins in infection is unknown. However, it has been described that LIP family members are differentially expressed during infection in specific areas of affected mucosae [35].

All strains of C. albicans expressed PLB1 and PLB2 (39/39) (Table 4). Recently, phospholipase activity was reported in strains of C. albicans and in nonalbicans strains from patients with vulvovaginal infections [36], as well as in different Candida species isolated from patients with type 2 diabetes mellitus suffering from VVC [37]. The elevated expression of phospholipase genes in the C. albicans strains isolated in this study (Table 4) suggests that these genes are essential for vaginal infection by participating in the breakdown of the cell membrane, which allows the hyphae to penetrate the epithelial cell cytoplasm [7].

The use of azoles for the treatment of VVC over time has resulted in the selection of strains resistant to these 


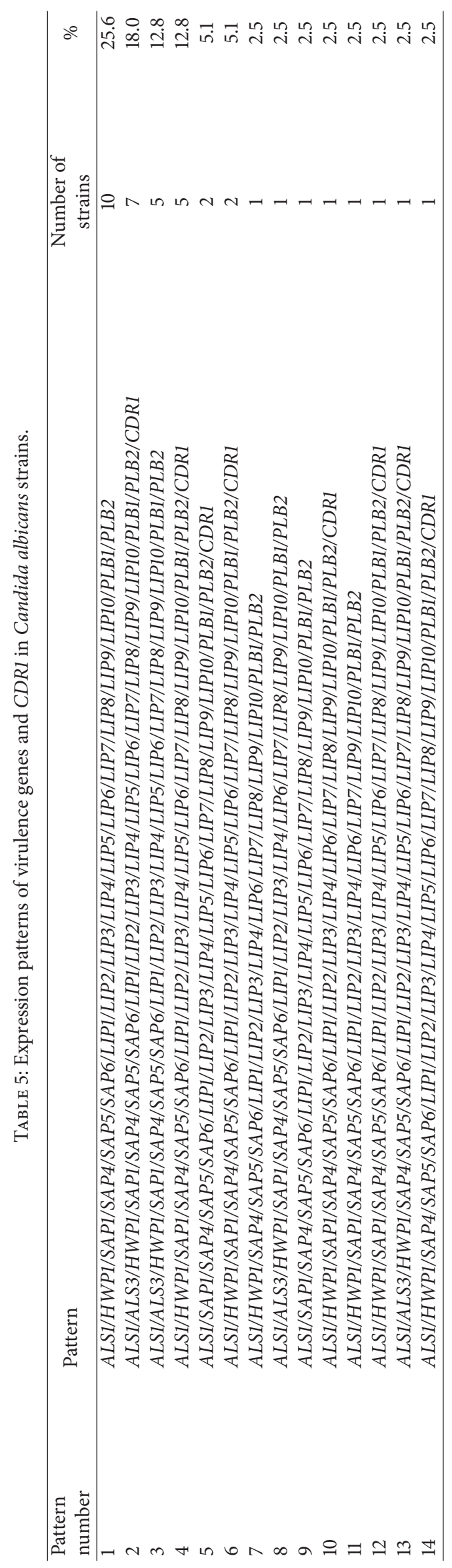


compounds [38]. In this study, the association of azole resistance phenotypes (fluconazole/ketoconazole) was identified in $94.9 \%(n=37)$ of the strains (Table 3), whereas CDR1 was found in only $66.6 \%(n=26)$ (Table 4$)$. This gap in detection can be explained by the idea that azole resistance is not only conferred by $C D R 1$, an $\mathrm{ABC}$ transporter, but may also be caused by the overproduction of an azole target, $14 \alpha$ demethylase, which is encoded by ERG11. Other mechanisms of azole resistance are caused by mutations in ERG11 which decrease azole affinity to this enzyme [10,39].

Interestingly, all strains described in this study were sensitive to nystatin $(n=39$, Table 3$)$, as also reported in other studies $[40,41]$. This result suggests that nystatin can be an alternative for the treatment of vaginal infections caused by strains of $C$. albicans which are resistant to azoles [42]. The high frequencies of strains resistant to fluconazole and ketoconazole (Table 3) can be explained by the high use of these two drugs (and clotrimazole) in Mexico, given that this is the most commonly used therapy against VVC. Our results are consistent with the observation that Candida species isolated in different geographical regions differ in their sensitivity to fluconazole [43].

In this study, we identified 14 distinct expression patterns of ALS, HWP1, SAP , LIP, PLB, and CDR1 in A431 cells infected in vitro with strains of $C$. albicans (Table 5). Pattern 1 , comprising 18 genes, was expressed by most strains (25.6\%). These findings show that, during the pathogenesis of infection, most virulence markers are expressed (in 8 of the 14 patterns). The combined expression of the azole resistance gene CDR1 with the virulence markers indicates that these strains are highly virulent and should be treated with a nonazole therapy.

\section{Conclusion}

This is the first work done in Mexico on global expression of different markers of virulence and resistance to azoles in clinical strains of C. albicans. The results show that the strains that infect Mexican patients suffering from VVC are highly virulent and virtually all are insensitive to azoles.

\section{Competing Interests}

The authors declare that they have no competing interests.

\section{Acknowledgments}

The Program UNAM-DGAPA-PAPIME PE203714 supported this work. The authors would like to thank Editage (http://www.editage.com) for English language editing.

\section{References}

[1] F. C. Odds, N. A. Gow, and A. J. Brown, “Toward a molecular understanding of Candida albicans virulence," in Molecular Principles of Fungal Pathogenicity, J. Heitman, S. G. Filler, J. E. Jr. Edwards, and A. P. Mitchell, Eds., pp. 305-319, ASM Press, Washington, DC, USA, 2006.

[2] J. D. Sobel, S. Faro, R. W. Force et al., "Vulvovaginal candidiasis: epidemiologic, diagnostic, and therapeutic considerations,"
American Journal of Obstetrics and Gynecology, vol. 178, no. 2, pp. 203-211, 1998.

[3] J. Hellstein, H. Vawter-Hugart, P. Fotos, J. Schmid, and D. R. Soll, "Genetic similarity and phenotypic diversity of commensal and pathogenic strains of Candida albicans isolated from the oral cavity," Journal of Clinical Microbiology, vol. 31, no. 12, pp. 3190-3199, 1993.

[4] J. D. Sobel, G. Muller, and H. R. Buckley, "Critical role of germ tube formation in the pathogenesis of candidal vaginitis," Infection and Immunity, vol. 44, no. 3, pp. 576-580, 1984.

[5] X. Zhao, S.-H. Oh, G. Cheng et al., "ALS3 and ALS8 represent a single locus that encodes a Candida albicans adhesin; functional comparisons between Als3p and Als1p," Microbiology, vol. 150, no. 7, pp. 2415-2428, 2004.

[6] B. Hube, "Possible role of secreted proteinases in Candida albicans infections," Revista Iberoamericana de Micologia, vol. 15, no. 2, pp. 65-68, 1998.

[7] M. A. Ghannoum, "Potential role of phospholipases in virulence and fungal pathogenesis," Clinical Microbiology Reviews, vol. 13, no. 1, pp. 122-143, 2000.

[8] B. Hube, F. Stehr, M. Bossenz, A. Mazur, M. Kretschmar, and W. Schäfer, "Secreted lipases of Candida albicans: cloning, characterisation and expression analysis of a new gene family with at least ten members," Archives of Microbiology, vol. 174, no. 5, pp. 362-374, 2000.

[9] M. Schaller, C. Borelli, H. C. Korting, and B. Hube, "Hydrolytic enzymes as virulence factors of Candida albicans," Mycoses, vol. 48, no. 6, pp. 365-377, 2005.

[10] L. Manastir, M. C. Ergon, and M. Yücesoy, "Investigation of mutations in Erg11 gene of fluconazole resistant Candida albicans isolates from Turkish hospitals," Mycoses, vol. 54, no. 2, pp. 99-104, 2011.

[11] E. Monroy-Pérez, T. Sáinz-Espuñes, G. Paniagua-Contreras, E. Negrete-Abascal, J. R. Rodríguez-Moctezuma, and S. Vaca, "Frequency and expression of ALS and HWP1 genotypes in Candida albicans strains isolated from Mexican patients suffering from vaginal candidosis," Mycoses, vol. 55, no. 3, pp. e151e157, 2012.

[12] E. Monroy-Pérez, G. Paniagua-Contreras, F. Vaca-Paniagua, E. Negrete-Abascal, and S. Vaca, "SAP expression in Candida albicans strains isolated from Mexican patients with vaginal candidosis," International Journal of Clinical Medicine, vol. 4, no. 1, pp. 25-31, 2013.

[13] H. Nailis, S. Kucharíkov, M. Řičicová et al., "Real-time PCR expression profiling of genes encoding potential virulence factors in Candida albicans biofilms: identification of modeldependent and -independent gene expression," BMC Microbiology, vol. 10, article 114, 2010.

[14] G. Luo and T. G. Mitchell, "Rapid identification of pathogenic fungi directly from cultures by using multiplex PCR," Journal of Clinical Microbiology, vol. 40, no. 8, pp. 2860-2865, 2002.

[15] G. L. Paniagua-Contreras, E. Monroy-Pérez, J. R. RodríguezMoctezuma, P. Domínguez-Trejo, F. Vaca-Paniagua, and S. Vaca, "Virulence factors, antibiotic resistance phenotypes and O-serogroups of Escherichia coli strains isolated from community-acquired urinary tract infection patients in Mexico," Journal of Microbiology, Immunology and Infection, 2015.

[16] M. A. Pfaller, D. J. Diekema, A. L. Colombo et al., "Candida rugosa, an emerging fungal pathogen with resistance to azoles: geographic and temporal trends from the ARTEMIS DISK Antifungal Surveillance Program," Journal of Clinical Microbiology, vol. 44, no. 10, pp. 3578-3582, 2006. 
[17] C. B. Green, G. Cheng, J. Chandra, P. Mukherjee, M. A. Ghannoum, and L. L. Hoyer, "RT-PCR detection of Candida albicans ALS gene expression in the reconstituted human epithelium (RHE) model of oral candidiasis and in model biofilms," Microbiology, vol. 150, no. 2, pp. 267-275, 2004.

[18] J. R. Naglik, F. Fostira, J. Ruprai, J. F. Staab, S. J. Challacombe, and P. Sundstrom, "Candida albicans HWP1 gene expression and host antibody responses in colonization and disease," Journal of Medical Microbiology, vol. 55, no. 10, pp. 1323-1327, 2006.

[19] B. Hube, C. J. Turver, F. C. Odds et al., "Sequence of the Candida albicans gene encoding the secretory aspartate proteinase," Journal of Medical and Veterinary Mycology, vol. 29, no. 2, pp. 129-132, 1991.

[20] J. R. Naglik, C. A. Rodgers, P. J. Shirlaw et al., "Differential expression of Candida albicans secreted aspartyl proteinase and phospholipase B genes in humans correlates with active oral and vaginal infections," Journal of Infectious Diseases, vol. 188, no. 3 , pp. 469-479, 2003.

[21] M.-K. Lee, L. E. Williams, D. W. Warnock, and B. A. Arthington-Skaggs, "Drug resistance genes and trailing growth in Candida albicans isolates," Journal of Antimicrobial Chemotherapy, vol. 53, no. 2, pp. 217-224, 2004.

[22] M. Schaller, H. C. Korting, W. Schäfer, J. Bastert, W. Chen, and B. Hube, "Secreted aspartic proteinase (Sap) activity contributes to tissue damage in a model of human oral candidosis," Molecular Microbiology, vol. 34, no. 1, pp. 169-180, 1999.

[23] M. Schaller, W. Schäfer, H. C. Korting, and B. Hube, "Differential expression of secreted aspartyl proteinases in a model of human oral candidosis and in patient samples from the oral cavity," Molecular Microbiology, vol. 29, no. 2, pp. 605-615, 1998.

[24] J. D. Sobel, "Vaginitis," New England Journal of Medicine, vol. 337, no. 26, pp. 1896-1903, 1997.

[25] G. Cheng, K. Wozniak, M. A. Wallig, P. L. Fidel Jr., S. R. Trupin, and L. L. Hoyer, "Comparison between Candida albicans agglutinin-like sequence gene expression patterns in human clinical specimens and models of vaginal candidiasis," Infection and Immunity, vol. 73, no. 3, pp. 1656-1663, 2005.

[26] L. L. Hoyer, J. Clevenger, J. E. Hecht, E. J. Ehrhart, and F. M. Poulet, "Detection of Als proteins on the cell wall of Candida albicans in murine tissues," Infection and Immunity, vol. 67, no. 8, pp. 4251-4255, 1999.

[27] L. L. Hoyer, T. L. Payne, and J. E. Hecht, "Identification of Candida albicans ALS2 and ALS4 and localization of Als proteins to the fungal cell surface," Journal of Bacteriology, vol. 180, no. 20, pp. 5334-5343, 1998.

[28] T. Nas, A. Kalkanci, I. Fidan et al., "Expression of ALS1, HWP1 and SAP4 genes in Candida albicans strains isolated from women with vaginitis," Folia microbiologica, vol. 53, no. 2, pp. 179-183, 2008.

[29] C. J. Nobile, H. A. Schneider, J. E. Nett et al., "Complementary Adhesin Function in C. albicans Biofilm Formation," Current Biology, vol. 18, no. 14, pp. 1017-1024, 2008.

[30] L. J. Douglas, "Candida biofilms and their role in infection," Trends in Microbiology, vol. 11, no. 1, pp. 30-36, 2003.

[31] C. H. Lian and W. D. Liu, "Differential expression of Candida albicans secreted aspartyl proteinase in human vulvovaginal candidiasis," Mycoses, vol. 50, no. 5, pp. 383-390, 2007.

[32] G. Newport and N. Agabian, "KEX2 influences Candida albicans proteinase secretion and hyphal formation," Journal of Biological Chemistry, vol. 272, no. 46, pp. 28954-28961, 1997.
[33] M. Borg-von Zepelin, S. Beggah, K. Boggian, D. Sanglard, and M. Monod, "The expression of the secreted aspartyl proteinases Sap4 to Sap6 from Candida albicans in murine macrophages," Molecular Microbiology, vol. 28, no. 3, pp. 543-554, 1998.

[34] F. Stehr, A. Felk, A. Gácser et al., "Expression analysis of the Candida albicans lipase gene family during experimental infections and in patient samples," FEMS Yeast Research, vol. 4, no. 4-5, pp. 401-408, 2004.

[35] D. A. Schofield, C. Westwater, T. Warner, and E. Balish, "Differential Candida albicans lipase gene expression during alimentary tract colonization and infection," FEMS Microbiology Letters, vol. 244, no. 2, pp. 359-365, 2005.

[36] S. R. Fule, D. Das, and R. P. Fule, "Detection of phospholipase activity of Candida albicans and non albicans isolated from women of reproductive age with vulvovaginal candidiasis in rural area," Indian Journal of Medical Microbiology, vol. 33, no. 1, pp. 92-95, 2015.

[37] R. H. Bassyouni, A. A. Wegdan, A. Abdelmoneim, W. Said, and F. Aboelnaga, "Phospholipase and aspartyl proteinase activities of candida species causing vulvovaginal candidiasis in patients with type 2 diabetes mellitus," Journal of Microbiology and Biotechnology, vol. 25, no. 10, article A021, pp. 1734-1741, 2015.

[38] S. S. Richter, R. P. Galask, S. A. Messer, R. J. Hollis, D. J. Diekema, and M. A. Pfaller, "Antifungal susceptibilities of Candida species causing vulvovaginitis and epidemiology of recurrent cases," Journal of Clinical Microbiology, vol. 43, no. 5, pp. 2155-2162, 2005.

[39] N. Alvarez-Rueda, A. Fleury, C. Logé et al., “The amino acid substitution N136Y in Candida albicans sterol $14 \alpha$-demethylase is involved in fluconazole resistance," Medical Mycology, vol. 54, no. 7, pp. 764-775, 2016.

[40] F. J. Wang, D. Zhang, Z. H. Liu, W. X. Wu, H. H. Bai, and H. Y. Dong, "Species distribution and in vitro antifungal susceptibility of vulvovaginal Candida isolates in China," Chinese Medical Journal, vol. 129, no. 10, pp. 1161-1165, 2016.

[41] F. Choukri, M. Benderdouche, and P. Sednaoui, "In vitro susceptibility profile of 200 recent clinical isolates of Candida spp. to topical antifungal treatments of vulvovaginal candidiasis, the imidazoles and nystatin agents," Journal de Mycologie Médicale, vol. 24, no. 4, pp. 303-307, 2014.

[42] J. M. Achkar and B. C. Fries, "Candida infections of the genitourinary tract," Clinical Microbiology Reviews, vol. 23, no. 2, pp. 253-273, 2010.

[43] Y.-L. Yang, H.-H. Cheng, Y.-A. Ho, C.-F. Hsiao, and H.-J. Lo, "Fluconazole resistance rate of Candida species from different regions and hospital types in Taiwan," Journal of Microbiology, Immunology and Infection, vol. 36, no. 3, pp. 187-191, 2003. 


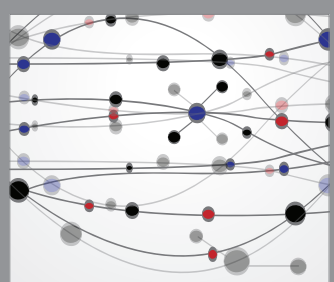

The Scientific World Journal
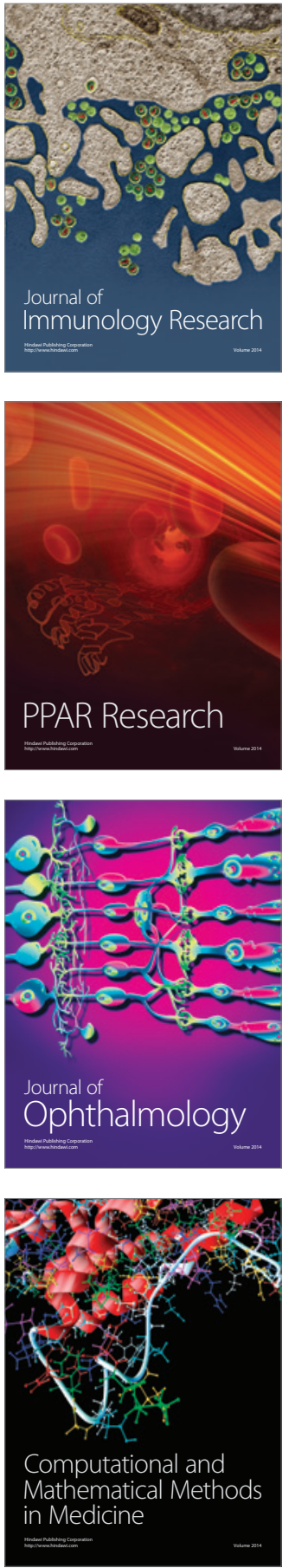

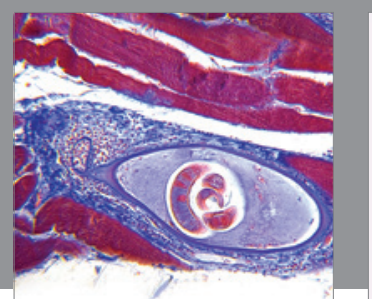

Gastroenterology Research and Practice

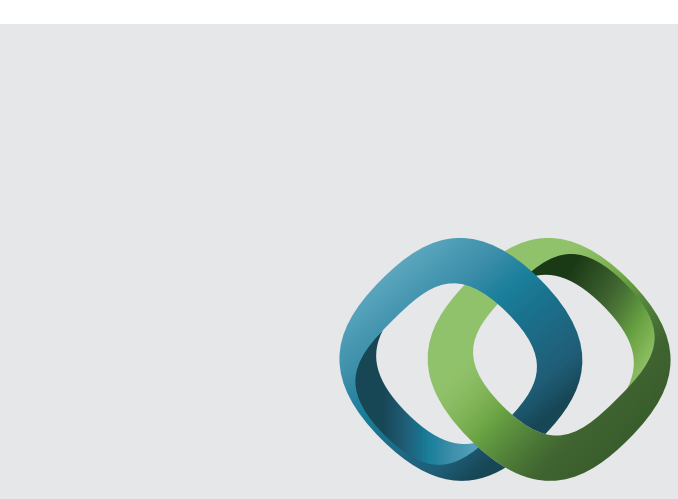

\section{Hindawi}

Submit your manuscripts at

http://www.hindawi.com
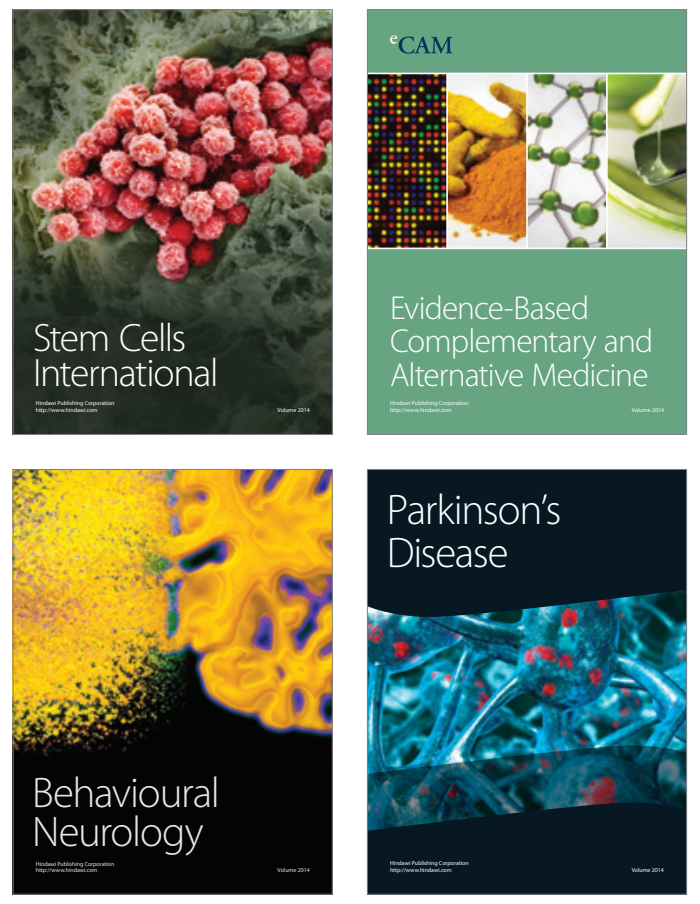
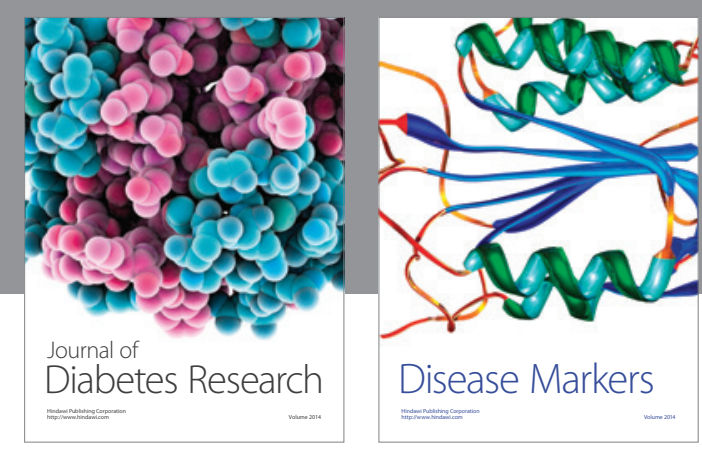

Disease Markers
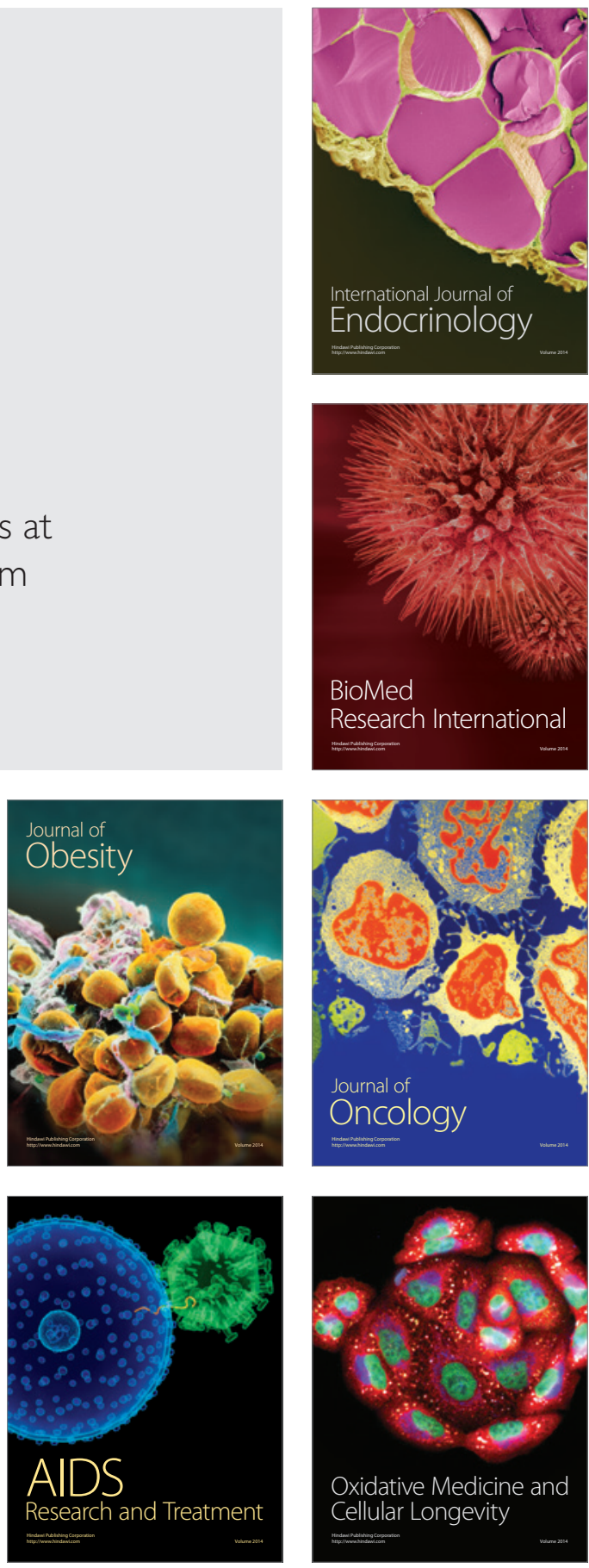